\title{
FROM UNSUNG HERO TO SAVAGE HERO: SHAPING CHARACTERS' ROLES IN THE ADAPTATION BETWEEN LITERARY WORKS AND MOBILE LEGENDS: BANG BANG! MOBA
}

\author{
Kriswanda Krishnapatria \\ Universitas Singaperbangsa \\ Karawang \\ kriswanda.krishnapatria@staff.unsika. \\ ac.id
}

\begin{abstract}
This paper examines adaptation study of famous heroes from various literary works (such as Mahabharata, Arthurian legend, Journey to the West) and a Multiplayer online battle arena (MOBA) 'Mobile Legends: Bang Bang!' (MLBB) by Moonton. This paper focuses on how fictional heroes and divine figures like Gatotkaca, Lancelot, Freya and Sun Go Kong are presented and shaped into different in-game roles. Mobile Legends: Bang Bang! a game designed for mobile phones, provides two opposing teams fighting one another to reach and destroy the enemy's base while defending their own base for control. Descriptive analytical method with documentation obtained from books and research journals was used to analyze the media; in addition, the theory used was based on Damono's theory of adaptation (2012) and Elleström's modalities (2010) by analyzing the element changes in the adaptation study. The conclusion is that the heroes' roles are shaped differently due to their true nature and motives from the original literary works.
\end{abstract}

\section{INTRODUCTION}

Multiplayer Online Battle Arena (henceforth MOBA) history begins with the merging of several types of online games. MOBA is an online game that combines Real-Time-Strategy Games (RTS), Action Games, and Role-Playing Games (RPG) where two teams fighting each other to destroy enemy bases. This genre has inherent characteristics, namely the use of 3-lane or classic 3-lane maps that can be used by players to go to enemy bases. The long journey of the birth of this genre originally began in the late 90 's.

In 1998, a famous American video game developer Blizzard Entertainment issued a phenomenal PC game known as STARCRAFT, along with a program to change the map or game area called STAREDIT. 5 years later in 2002, Blizzard Entertainment released a legendary RTS game entitled WARCRAFT III: Reign of Chaos. With the advent of WARCRAFT III: Reign of Chaos, the in-game map was then transformed into a new game called Defense of the Ancient (DoTA). In2009, Riot Games, another American video game developer, and eSports tournament organizer, released a similar game to DoTA for Androids and iOS named League of Legends. From this time on, Riot Games paved and popularized this game type as MOBA.

Technological sophistication makes MOBA not only be enjoyed on PC platforms but also smartphones. To date, several MOBA games that have entered the Indonesian market, the most popular among which are Vainglory (2014), Arena of Valor (2015), Mobile Legends (2016) and others. Generally speaking, today's[11] online mobile games are undoubtedly rife in the community, and surprisingly the enthusiasts are indiscriminately ranging from children to adults. Online games have mushroomed from a long time in Indonesia, and the spread was indeed very fast, especially in the last few years. MOBA players are getting more crowded in Indonesia than ever, and annual tournaments have been held several times with big prizes resulting in the flourishing of e-Sports genre across the nation.

MOBA on the smartphone itself has similar gameplay and mission compared to PC version though it has slightly different controls, especially in Mobile Legends: Bang Bang! (henceforth MLBB) where the player uses a virtual joystick control (like analogue controllers on video game console) to move the heroes. This MOBA game successfully stole the attention of mobile gamers in Indonesia since 2016 due to its distinctive heroes. A hero is a unique character that can only be played by one player in each round of the game. Interestingly, some heroes that appear in MLBB were originated from some famous epics across the globe.

One of the most essential things a player should know when playing Mobile Legends is learning 


\section{Kriswanda Krishnapatria}

the different types of hero roles. That is because every hero has a specific role (sometimes even more) depending on its skills and abilities. Specifically, there are six hero roles in MLBB: Fighter, Assassin, Mage, Marksman, Support and Tank. Each role has its own set of duties in-game, and each team will need a synergy to strike a balanced combination of roles to create a strong team composition to ensure they have the highest chances of winning every game. It is interesting to know that the depiction of famous heroes' roles in MLBB is based on their original background story from literary texts.

Names such as Gatotkaca and Freya summon up mythic legends, while Lancelot and Sun (Wukong, also known as the Monkey King) are some of the most recognizable characters in the world of literature. They are all memorable characters and great heroes that have lasting power due to their bravery and fortitude. Despite being born in the ancient times and medieval era, these heroes' existence has been so influential to the modern days that they have inspired countless writers, artists, and now game developers present these figures in popular culture. Moonton is one of few game developers that has successfully adapted and transformed these important characters into unique MOBA heroes that have attracted tons of players to try and play the game MLBB. In fact, Cayayan (Adzani, 2018), Moonton Indonesia Country Manager, stated that "In Southeast Asia there are a total of 43 million MLBB players, while Indonesia has the most, about more than 50 percent", which means that there are at least more than 20 million Indonesians playing Mobile Legends when the research commenced.

Perhaps the introduction of these heroes has somewhat popularized the mobile game since they hold special places in our memory and imagination. As a fan of the Sanskrit epic of Mahabharata, I was interested in the game because of my curiosity in playing the hero Gatotkaca. However, in spite of being familiar with the mentioned heroes' names, not everyone who plays MLBB knows exactly where the heroes' story originates and why they have distinctively particular roles in the game (such as Gatotkaca's role is a tank, while Lancelot serves as an assassin). Since to date Mobile Legends has not been extensively studied, this research is more likely the first to fill the research gap in terms of in-game content. To seek a comprehensive understanding, this research will strive to answer the main research question: "How are the characters' roles shaped in the adaptation from literary texts to MLBB MOBA?". In short, I delved into selected heroes' story original texts and explore the notable impact of these characters on Mobile Legends heroes' roles.

\section{METHOD}

This research used descriptive-analytical method which is research to obtain information concerning the current status of a phenomenon. The results of this study were then processed and analyzed to make conclusions. This study is considered descriptive due to its aims to explain the transformation of the hero characters of the great epics, namely Gatotkaca, Freya, Lancelot, and Sun to their new roles in the adaptation from literary works to Mobile Legends MOBA.

When I set out to study the heroes' adaptation from text to game Mobile Legends MOBA, I naturally played the game and created an account to play all characters to be analyzed. According to the in-game statistics, I have started playing the game since 6 March 2018. My only primary account, named kukifuruya after my nickname in real life, was not only used to study Mobile Legends but also to develop the early principles of the hero/character adaptation from literary texts to contemporary popular culture.
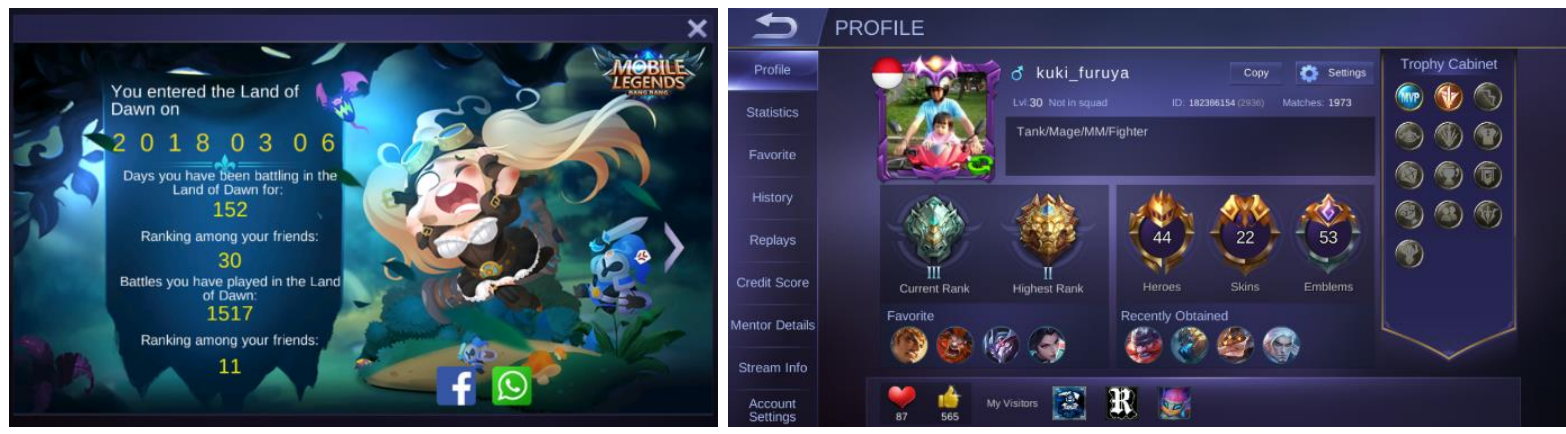

Figure 1. Author's MLBB Account showing in-game statistics and profile page

Further, in the adaptation of works (Damono, 2009: 121)-in this case from literary text to mobile games-there were several changes. The transformation of these media includes four modalities (Elleström, 2010: 15), namely material modalities, five senses modalities, temporal space modalities, and semiotic modalities. Those modalities were used to analyze the impact of element changes in the adaptation. 


\section{FINDINGS AND DISCUSSION}

\section{Hero's role in Mobile Legends: Bang Bang!}

Mobile Legends is one type of game that relies on team cohesiveness. Therefore, the composition of the team with the right roles is very important to win the game. The role is the division of tasks in the game. Generally, roles are defined to maintain the team's synergy and cohesiveness Based on their characteristics, the heroes in MLBB are classified into the following roles:

1. Marksman - This type of hero has a strong attack power, so it has the role of the main attacker (carry) in the game.

2. Tank - This type of hero has a large base of Health Points (HP) and Armor so that it can receive large damage from opponents to protect the team.

3. Mage - This type of hero has a magical skill with great damage, so it can do a quick kill to the opponent's hero.

4. Support - This type of hero has skills that are useful for guarding the team and assisting the team while fighting.

5. Assassin - This type of hero generally has skills that can swiftly kill and lock opponents.

\section{Gatotkaca, Mighty Legend (Role: Tank)}

Gatotkaca, who was the son of Pandava's Bhima and Arimbi-a rakshasa, is a notable character in Sanskrit Epic Mahabharata (Datta, 2006). His maternal parentage made him half-Rakshasa and gave him many magical powers such as the ability to fly without wings, and is famous for the nickname "steel bone, iron muscle". According to Hardjowirogo (1982), little Gatotkaca was beaten to near-death by Sekipu, yet strangely, the more he was beaten, instead of dying, the stronger little Gatotkaca became. This strength was then presented in MLBB as the hero's passive skill which is converting $4 \%$ lost HP to his physical defense, making him strongest when nearly death. In the game Gatotkaca posseses magical power which was originally derived from the original story. In the original story, he obtains the supernatural power from the ultimate training inside the cauldron of heaven, Candradimuka (Hardjowirogo, 1982).

In the story, both of the twin souls of his uncles Brajamusti and Brajadenta resided into Gathotkaca's hands and added his strength. In the game, these attributes are visually manifested in his notable twin gauntlets, with which he can fly across the skies like lightning and hunt down his enemies. His ultimate skill in the game, Avatar of Guardian, perfectly illustrates the given description where the hero flies and jumps to the designated area, knocking nearby enemies.

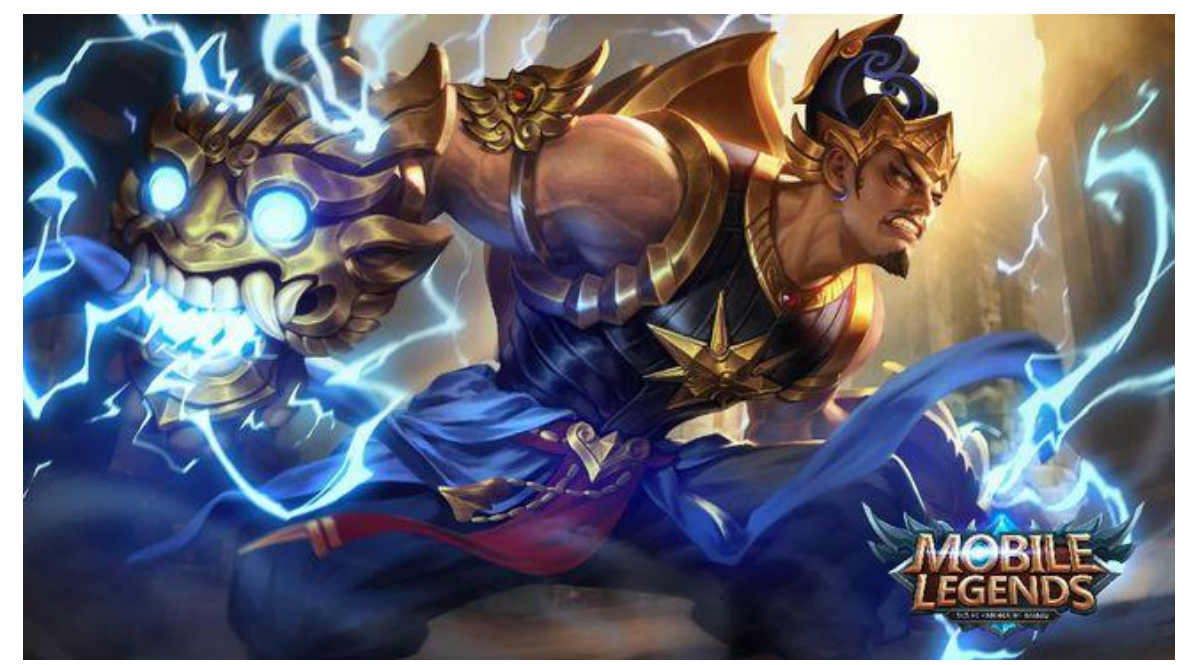

Figure 2. Gatotkaca hero with Antakusuma armor and Brajamusti-Brajadenta twin gauntlet

His voice-over in the game, "We are unity in diversity", is in fact, Indonesia's national motto Bhinekka Tunggal lka referring to the variety in the game's internal composition and also indicates that-despite all differences in its roles - there is a true sense of players' unity to obtain victory in the game. Another in-game quote "Legends never surrender" is derived from Gatotkaca's strong resolution to fight until the last breath 


\section{Kriswanda Krishnapatria}

during Kurukshetra war when he was mortally wounded by Karna. These original background story and attributes associated with Gatotkaca have ultimately made him a Tank in the game.

\section{Freya, Goddess of War and Sun, Monkey King (Roles: Fighter)}

In Norse mythology and religion, Freya is a goddess associated with love, beauty, war, and death (McCoy, 2016). Freya is famous for her fondness of love, fertility, beauty, and fine material possessions (The Poetic Edda. Lokasenna, stanzas 30, 32). According to one old Norse poem, she chose half of the warriors slain in battle to dwell there. Despite her association with death, Freya was never a terrifying goddess, for the Scandinavians knew she was the essence of love and beauty. In the game, Freya loses her divinity and spiritual attributes and becomes a fighter. Eventhough Freya plays the role of a fighter, her ultimate skill Valkyrie allows her to enter Valkyrie mode, dealing with physical[12] damage to surrounding enemies and slowing them down. In the meantime, the hero's physical attack, armour, and magic resistance increase. Valkyrie enables Freya to turn "God-mode" and cleaves through the enemies.
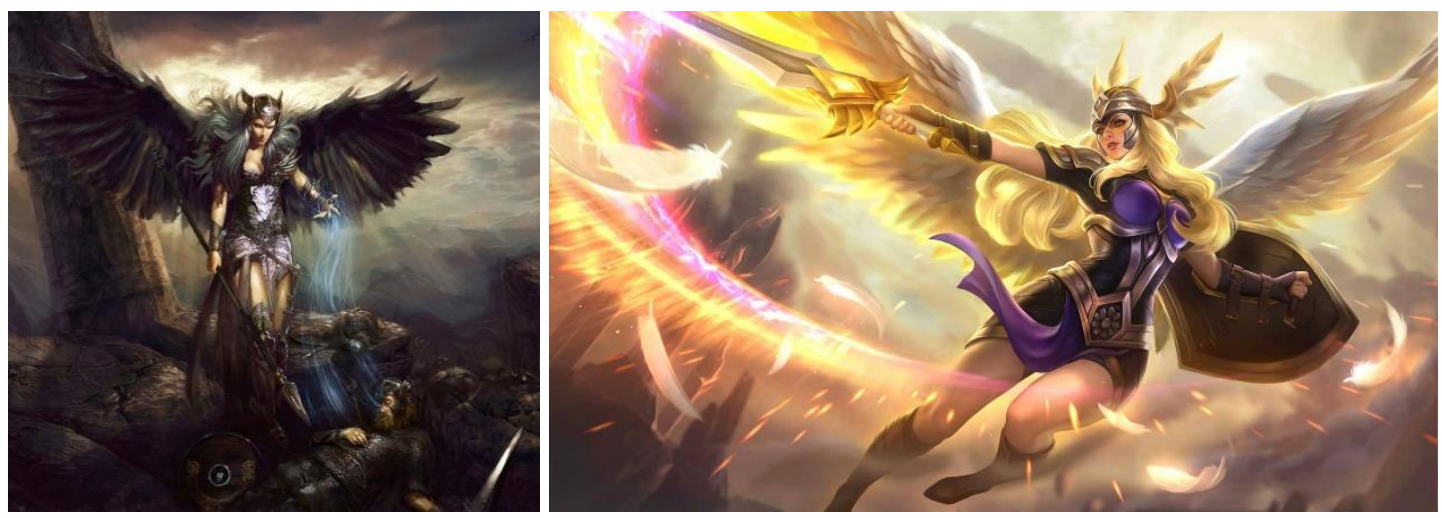

Figure 3. Freya as the Ruler of Death in Norse Mythology (left) bears a resemblance to Freya in her Valkyrie mode in MLBB (right)

There is one old Norse poem saying: When a warrior dies on the battlefield, the goddess of war Freya will come down from heaven, kiss the spirit of the fallen, and lead it to the Temple of Heroes, where former warriors can have a new life (Ellis, 1968). In MLBB, Freya refers to the story by regularly saying "The Spirits will be with us" portraying herself as an outstanding warrior who can both attack and defend with her sword and shield, making her as a beautiful fighter.

Similarly, the playable character Sun who is originally adapted from Journey to the West, a Chinese novel published in the 16th century during the Ming dynasty, has the role of a fighter in the game. The protagonist Sun Wukong, also known as the Monkey King, a skilled warrior who possesses immense strength and is capable of defeating the best warriors of heaven (Cheng'en, 1993).

Wukong in the early story of the novel's version is portrayed as a vile character, who was capable of wreaking havoc in heaven, fighting off its most powerful generals, even challenging Buddha himself. His ferocious temper and arrogance, or better yet over-confidence, is reenacted in the game as he frequently says: "I hope they're stronger than me" or "Show me some real challenges". Later in the story, having been imprisoned for five hundred years, Sun Wukong serves as a guard for a pilgrim on a journey to the West to retrieve the Buddhist sutras in exchange for his freedom. During the journey, Sun Wukong learns about virtues and the teachings of Buddhism. There, Sun Wukong is granted Buddhahood, becoming the "Victorious Fighting Buddha" for his service and strength. In the game, Sun often says, "Every mistake could be a lesson" to convey that he has transformed into a better character after the journey. In the game, Sun is also granted power in the form of Battle Buddha's skin which is similar to the original story. 


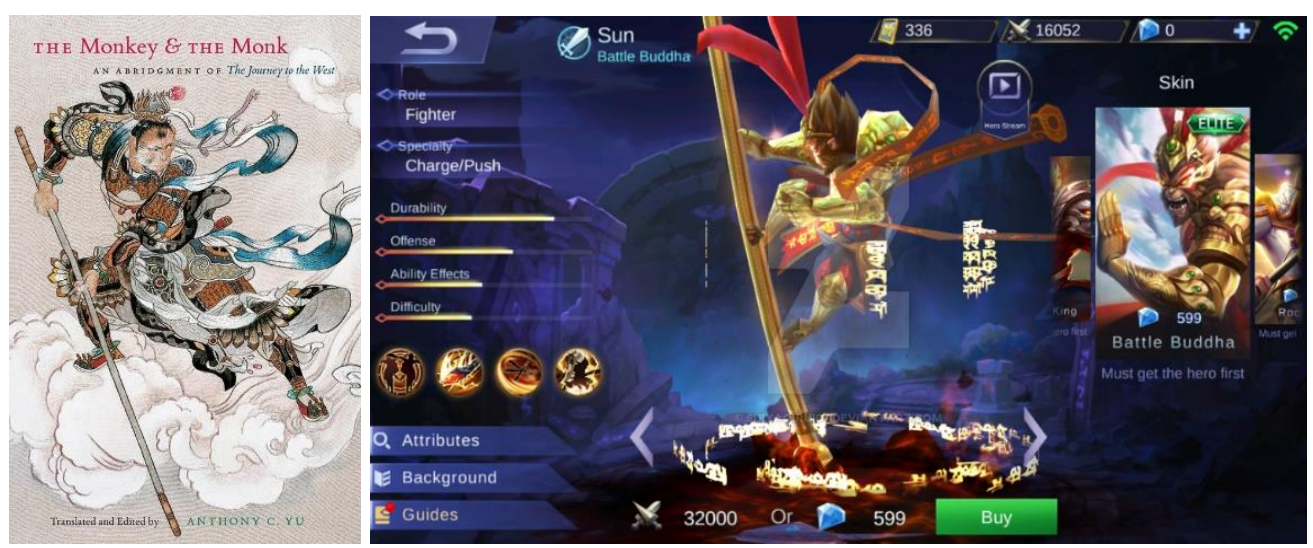

Figure 4. victorious Battle Buddha Sun Wukong from Journey to the West and Battle Buddha Sun from Mobile Legends are wearing magical gifts, including golden chain mail, a phoenix-feather cap, and cloud-walking boots

The legend said that Sun Wukong was given three special hairs by Guanyin (who received them from the Buddha himself), which could be used in dire emergencies. All the other hairs possess magical properties, capable of being transformed into clones of the Monkey King himself. Similar to the original story, Sun is a hero who possesses clone technique as his ultimate skill and passive skill in summoning monkeys. His other skill is the golden cudgel strike which he and his doppelganger use the golden cudgel to smash his enemies. In the original story, Wukong uses it to fight off, making him as a formidable warrior.

\section{Lancelot, Perfumed Knight (Role: Assassin)}

Lancelot is one of the most prominent knights of the Round Table in the Arthurian legend. $\mathrm{He}$ is regarded as a skilled knight with flaw in personality. He was not mentioned in the first tales about King Arthur but became popular in French Arthurian legends after the Middle Ages. When tales about King Arthur were rewritten by Thomas Malory (1485), with the approval of the Roman Catholic Church, Lancelot was depicted as one of the main characters who caused contention in King Arthur's Round Table due to his love affair with King Arthur's wife, Guinevere (MacBain, 1993). Unlike other previous heroes' roles, this background story then perhaps made Lancelot as an assassin in MLBB.

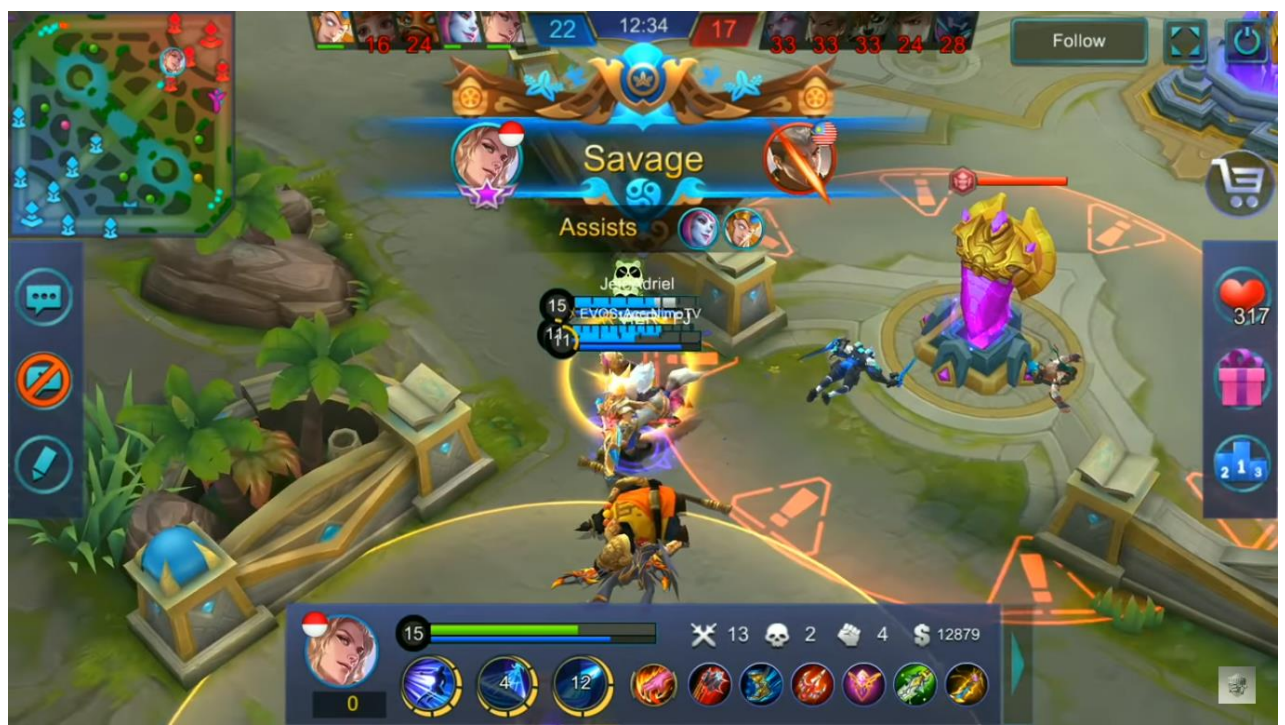

Figure 5. From unsung hero in Arthurian Legend, Lancelot becomes a savage hero in MLBB

In the game adaptation, his love interest Guinevere is replaced by Princess Odette. Her admiration of Odette's purity is the equivalent factor that drives Lancelot to set foot in the fighting ring. He often proclaims, "Odette, beautiful Odette" and painfully says "Odette..." upon his death in the game to show his strong affection. Lancelot, along with Gatotkaca and Freya, is unsung heroes in their literary works compared to the well-known King Arthur, Arjuna, and Thor. However, the mobile game put these characters in the spotlight by getting kill achievement. Lancelot with his high burst damage is by all means one of the 


\section{Kriswanda Krishnapatria}

strongest assassins in the game that enables players to achieve "savage" (kills five enemy heroes at once) level, which is often considered as the most prestigious personal achievement yet the most difficult and challenging to attain. Even after playing the game for 7 months and managing to get to top tier rank Legend, getting a savage is still beyond my reach.

\section{Analysis of Modalities in the Adaptation between MLBB and the Literary Works}

Each hero mentioned has distinctive character and story; when they are adapted to the new media of mobile games, new changes occur in terms of modalities. Thus, this section will focus on the changes in modality aspects of the adaptation. There are four types of modalities, namely (1) material, (2) five senses, (3) temporal, and (4) semiotic, and each modality notably marks important transformation between the two media. In terms of material modality, all characters are originally taken from great epics (Mahabharata and Poetic Edda) and chivalry tales (Arthurian Legend and Journey to the West). The epics are the forms of artistic expression and entertainment, which play a significant social and cultural function in society. As part of the oral tradition, they embody knowledge, art, ideas and cultural material, which are received, preserved and transmitted orally through generations. oral tradition wherein is received, preserved and transmitted orally from one generation to another. When they are adapted into MLBB, the heroes undergo an inevitable transformation. In the game, players should control the heroes from their gadgets. Each hero is constructed based on his/her true nature from the original texts. Furthermore, unlike reading books for pleasure, playing MLBB will bind their players to finish each game mode (Classic, Ranked, or Brawl) at a certain time to avoid severe penalty.

When it comes to five senses modality, the game undoubtedly presents a livelier and interactive game or entertainment due to its audio and visual features. Some of the dialogues and important events from the original literary works are presented in the heroes' speech and the in-game skills. Consequently, this has successfully transformed the respective figures to the new media while preserving their identities. Temporal and space modalities go without saying become the most distinctive feature in which Gatotkaca from ancient Indian Hastinapur, Freya from Scandinavia region, Wukong from ancient China, and Lancelot as a British Medieval knight, assemble together in the fictional world of The Land of Dawn where the two battlegrounds and the places of origin of the heroes in Mobile Legends are located. Ultimately, the in-game mini-map on the top left of the screen can give players quick information about various things, such as teammate position, approximate enemy locations, lord or turtle places, ping/connection notifications and more. Semiotic modalities in the adaptation are represented in the new symbols, icons, and indexes of the heroes for the online MOBA, which are based on the original texts.

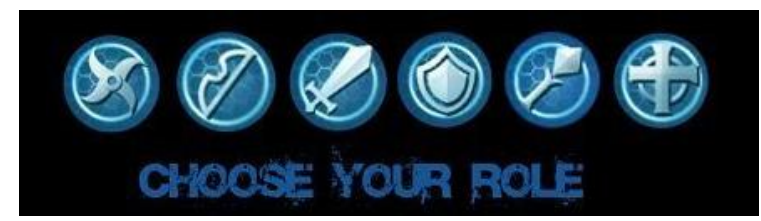

Figure 6. Symbols of heroes' roles in Mobile Legends

(from left to right: Assassin, Marksman, Fighter, Tank, Mage, and Support)

\section{CONCLUSIONS AND SUGGESTIONS}

After examining the adaptation between the literary works and MLBB MOBA, it can be concluded that the four famous heroes Gatotkaca, Freya, Sun, and Lancelot have differences based on modalities. The first factor is different material modalities in which the written works are not constrained by duration, yet the mobile game is constrained by the duration of each round as well as heroes' roles in the game, so their roles are shaped based on each background story. The second factor is the five senses modalities (audio and visual). In the literary works, the stories are presented using detailed description of imagery and dramatization of narrative to evoke readers' emotions-because they are only in the form of 'silent' writing, while in the game adaptation, these dramatic effects are generated using background music, heroes' speech, and visual animation which represents the meaning of the scene and action.

The third and fourth factors are the temporal and semiotic modalities. Both factors are related to the meaning of the story. Temporal and space modalities affect the various setting of the stories for each character whose original settings are merged into one fictional Mobile Legends arena called the Land of Dawn. Last but not least, semiotic modalities have transformed the verbal signs from the literary texts into distinctively meaningful symbols, images, and icons that represent the heroes' roles in the game.

\section{REFERENCES}

Azani, Fadli. (2018, July 17). Ini Jumlah Pemain Mobile Legends di Indonesia yang Diungkapkan Moonton. Retrieved from http://hai.grid.id/read/07900603/ini-jumlah-pemain-mobile-legends-di-indonesia-yangdiungkapkan-moonton?page=all

Cheng'en, Wu. (1500-1582). Journey to the West (Translated by Foreign Languages Press, Beijing 1993). 
Damono, Sapardi Djoko. 2012. Alih Wahana. Jakarta: Editum.

Damono, Sapardi Djoko. (2009). Sastra Bandingan. Jakarta: Editum.

Datta, Amaresh. (2006). The Encyclopedia of Indian Literature (Volume One). Kolkata: Sahitya Akademi.

Ellestrom, Lars (ed). (2010). Media Borders, Multimodality, and Intermediality. Hampshire: Pallgrave Macmillan.

Ellis, Hilda Roderick. (1968). The Road to Hel: A Study of the Conception of the Dead in Old Norse Literature.

Hardjowirogo. (1982). Sejarah Wayang Purwa. Jakarta: Balai Pustaka.

MacBain, Danielle Morgan (1993). The Tristramization of Malory's Lancelot. English Studies.

Malory, Sir Thomas. (1950). Lanier, Sidney, ed. King Arthur and His Knights of the Round Table. Grosset \& Dunlap

McCoy, Daniel. (2016). The Viking Spirit: An Introduction to Norse Mythology and Religion. Unknown publisher.

Moontoon. (2016). Mobile Legends: Bang Bang!. Mobile game. China: Sanghai Moonton.

The Poetic Edda. Lokasenna, stanzas 30, 32 